Article

\title{
Models of Subsidies for Water and Sanitation Services for Vulnerable People in South American Countries: Lessons for Brazil
}

\author{
Daniel Antonio Narzetti *(D) and Rui Cunha Marques \\ Civil Engineering Research and Innovation for Sustainability (CERIS), Instituto Superior Técnico, Universidade \\ de Lisboa, Av. Rovisco Pais, 1049-001 Lisbon, Portugal; rui.marques@tecnico.ulisboa.pt \\ * Correspondence: daniel.narzetti@tecnico.ulisboa.pt; Tel.: +351-218-418-310
}

Received: 9 June 2020; Accepted: 7 July 2020; Published: 13 July 2020

check for updates

\begin{abstract}
Access to water and sanitation services (WSS) in developing countries is constrained by the conditions of social inequality and the services affordability for the poorest households. Therefore, public policies related to WSS need to broaden in scope given the challenge of reaching all customers, especially the most vulnerable, in order to achieve a balance between the social and financial objectives of WSS. This paper will contribute to the understanding of the main access and subsidy policies in South American countries focusing on the Brazilian case study. The different experiences in this region have provided some interesting lessons about these issues for Brazil; the conclusion is that the current indirect and cross-subsidy policies are important, but the needed practices for expanding pro-poor access require direct demand-side subsidies. A more proactive intervention through public authorities is also needed. A new subsidization model for Brazil is highlighted and discussed.
\end{abstract}

Keywords: subsidies; South American countries; Brazilian pro-poor public policy

\section{Introduction}

In recent years, urban and regional planning has undergone an unparalleled increase in the degree of complexity and demand as a result of the challenges involved in developing social and territorial cohesion and improving environmental recovery. Organizations that are part of public service infrastructure, including water and sanitation services (WSS), are often examples of monopolistic industries that require both economic and social and environmental viability, often ensured by tariffs on customers' usage of these services. Unequal distribution of income and the concentration of poor households in peri-urban and rural areas require specific investments and differentiated payment conditions for connection to the services. Thus, inclusive public policies for expanding access, including efficient subsidy models for poor and vulnerable households, are key for the economic and social cohesion of the population. Moreover, in most regions usually there are no alternative suppliers, so customers are sometimes compelled to accept the imposed conditions without questioning them [1]. This circumstance, besides leading to inadequate prices, also causes the deterioration of the quality of service and makes the service less attractive to customers, thus affecting their willingness to pay. Most of the time, suppliers have high levels of inefficiency and serious governance problems. Therefore, all stakeholders lose because they are unable to ensure the maximum amount of social welfare. In addition, these issues particularly penalize the most vulnerable population that is deprived of these essential services [2,3].

This research aims to discuss the WSS subsidy models for poor households in South American countries and to draw out lessons for Brazil, which still lacks a clear public policy on this matter. Worldwide cross-subsidization has typically been implemented through the different tariff structures, 
such as fixed and variable tariff or increasing block tariff structures (IBTs), where households that consume smaller amounts of water and generate less wastewater pay less per cubic meter than households that consume more, as a revenue sharing mechanism. However, subsidies seldom are well targeted to the poor since they tend not to be connected to water or sanitation networks to the same extent as other groups in the population as a result of living far from the existing networks and because connection costs tend to be high and unaffordable [4,5]. Furthermore, the underlying assumption that low-income households use less water than high-income households may simply not be accurate in many contexts in developing countries [6]. Other ways of cross-subsidization, such as between customer groups, areas served or even services provided, are also often utilized [1].

Universal access to adequate WSS is recognized as essential to public health and individual well-being. In most countries, government policy maintains service providers as public entities or enterprises and artificially lowers tariffs through different forms of subsidies in a more or less explicit way [7]. The result of such policies has been unsatisfactory, since the quality of service and coverage remain inadequate, and the targeted subsidies of the public utilities often benefit the middle class rather than lower income households that remain disconnected from the public network [8]. Inclusive public policies that provide subsidies should be implemented to facilitate the access of low-income households to these services, thereby protecting their access to a universal right while avoiding exclusion and the occurrence of infectious diseases due to deteriorating hygiene conditions and sanitation [9].

The literature is abundant on the subsidies in the water sector. There are many studies that examine how well the tariff structure ensures subsidies for poor households $[4,10-16]$ or that compare the performance of subsidy allocation [8,17]. Some researchers explicitly compare the performance of subsidies based on the quantity consumed and subsidies for access [18]. However, few studies make an international comparison, and as far as the authors know, no one has dealt with the WSS subsidization scheme in Brazil. Therefore, this paper will address this issue for each country in South America with focus on Brazil.

This research will review the literature on subsidy models and discuss how such models are being adopted in South American countries in the water sector. It mainly focuses on urban network systems, which is recognized as a limitation. The paper is structured as follows. After this introduction, the second section analyzes the current conditions for access to WSS in South American countries. The third section discusses a categorization of subsidy models for water and sanitation tariffs. The fourth section displays the case of Brazil along with its regional specifications and provides some recommendations for improving universal access to WSS in the country. Finally, the fifth section draws the main concluding remarks.

\section{Access to WSS in South America}

The WSS in South America took their first great step in the 1980s with the establishment of infrastructure development policies for urban population services. In the late 1990s and early 2000s, a second reformulation of public policies for water and sanitation took place in these countries, redefining public sources of funding and opening up the industry to the private sector. This section, through the exploratory research method, analyzes each South American country to illustrate the different levels of WSS coverage, the progress in the WSS, the current tariff structure and the policy of tariff subsidies adopted to provide basic access to these services for poor and vulnerable people. The examples of Argentina, Bolivia, Brazil, Chile, Colombia, Paraguay, Peru and Uruguay are next described and discussed. 


\subsection{Access to WSS}

\subsubsection{Argentina}

In Argentina, it is estimated that of the 44 million inhabitants, $84.4 \%$ have access to water and $58.4 \%$ to sanitation through the public network. Over the last 10 years, the country has increased coverage by $4 \%$ for the water services and more than $10 \%$ for sanitation. There are no reliable statistics on the level of wastewater treatment. However, some sources estimate that between $15 \%$ and $20 \%$ of what is collected is treated. The coverage gaps intensify and directly affect the most vulnerable social sectors. The coverage of the water network can be understood in two different dimensions: areas with indicators of unsatisfied basic needs (necesidades básicas insatisfechas-NBI), where there is $73 \%$ coverage, and areas that do not experience NBI, where coverage rises to $85 \%$. For the sanitation network coverage, populations with NBI indicators have $31.2 \%$ coverage, while in sectors without NBI indicators, there is $56.3 \%$ coverage. This demonstrates that the most vulnerable areas need more investment in order to expand the coverage of basic needs [19]. Argentina has 23 provinces and the Autonomous City of Buenos Aires. Given the multiplicity of direct and cross-subsidy systems and the social tariff in these different jurisdictions in Argentina, it is not possible to compare the situation of each system. Usually the WSS tariff system has two parts, one fixed and one variable, depending on consumption. The fixed tariff for water and sanitation in Buenos Aires in AySa is calculated by multiplying three coefficients (i) universal daily contribution, (ii) modification coefficient, and (iii) service factor. The variable part is also calculated through relationship between factors, such as excess consumption to bill, modification coefficient, service factor, geographical area, consumption category, covered surface, building surface and terrain surface. The importance and influence of these factors depend on the existence of metering and on the households' income.

The policy of tariff subsidies changed in 2015 in Buenos Aires. The customers who were in the social tariff program until then had benefited from the general subsidy policy, but then, the competition between policies reduced the attractiveness of the social tariff program whose rate of renewal dropped. The low attractiveness of this program resulted in a lower number of customers benefiting from the social tariff: approximately 14 thousand customers in the Buenos Aires region. The 2016 tariff increased, and the new social tariff program changed this scenario; as a result, the number of beneficiaries increased approximately 18 times, reaching more than 250 thousand customers in that region [20].

The Water and Sanitation Regulatory Agency (Ente Regulador de Agua y Saneamiento-ERAS), through Normative Resolution no. 61 of 2017, defined rules for the eligibility to the social tariff in the Buenos Aires region, which subsidizes access to and use of the service. This subsidy applies to customers who request it and can be used in the following ways: (i) the social tariff can be applied towards the total or partial payment of the connection to potable water and/or sanitation networks for residential customers; (ii) the social tariff can have effects over the total or partial payment of current billings for the drinking water supply and/or sanitation for six consecutive two-month periods (one year), and the customer can request the renewal of the tariff if the necessary conditions for the granting of subsidy are fulfilled; and (iii) the social tariff can be used to regularize non-payment to settle the debts that the customer has accumulated due to the same reasons that prevent full payment at the current rate. The beneficiary population of the Social Tariff Program for access to WSS is divided into the following categories: (a) households with low resources and/or difficulty paying for WSS, whether permanent or transitory; (b) households in critical social situations (income limited to food expenses or the presence of minors, dependent elderly, disabilities, chronic diseases, etc.); (c) public bodies that are civil associations, simple associations that directly or indirectly seek profit or nonprofit community organizations, including universities, public schools, and sports entities. In all cases, to operationalize the program, the analysis considers each mechanism of access where the customer has the subsidy approved only after requesting it by filling out a form and providing documentary evidence. 


\subsubsection{Bolivia}

In Bolivia, water coverage reaches an average of $85.6 \%$ of the population, and sanitation reaches only $59.2 \%$ of coverage at the national level [21]. Currently, the national government policy contributes to the expansion and construction of water and sanitation systems that are transferable to municipalities while, at the same time, some of these systems are transferred to the corresponding Public Sanitation and Water Companies (Empresas Publicas de Saneamiento e Agua-EPSA) that operate and manage the WSS. Most EPSAs categorize customers according to their characteristics; residential, commercial or industrial. Tariff systems include fixed and variable tariffs, but the variable part of the tariff follows the IBT scheme, thus allowing cross-subsidies between customers. A relevant mechanism for ensuring WSS affordability in Bolivia was the implementation of the solidarity residential tariff for the poor population with a discount in the fixed tariff and in the variable tariff up to $10 \mathrm{~m}^{3}$ in relation to the residential tariff and a solidarity tariff for seniors over 60 years old and homes with social activities, which is a fixed tariff for consumption that does not exceed $15 \mathrm{~m}^{3}$ and is applicable to all EPSAs in the country. However, their implementation is difficult in small EPSAs where most customers follow the same pattern of low residential consumption [22]. Concerning the WSS tariff in Sucre, for example, the fixed part varies according to the type of customer and the variable part has eight blocks of prices according to the consumption increase and the solidarity tariff is lower than the residential one, $4 \%$ in the fixed part and $7 \%$ in the variable part up to $10 \mathrm{~m}^{3}$.

The willingness to pay for WSS contrasts with the deficiencies concerning network coverage, continuity of service and drinking water quality. In Bolivia, when customers are dissatisfied with the services provided, they are unwilling to pay more for their water bill. Therefore, universal access to WSS involves a broader reform focused on customers' payment capacity and the quality of the service provided, aligned with a policy to increase the income of the poorest households, allowing them to pay fair prices for water without jeopardizing their satisfaction of other needs [23].

To recover the investments made in providing WSS to low-income households, the utilities may increase the regular prices for other Bolivian customers, which vary according to each customer's category. The Authority for the Supervision and Social Control of Water and Sanitation Services (Autoridad de Fiscalización y Control Social de Agua Potable y Saneamiento Básico-AAPS), through article 55 of Law no. 2.066 of 2000, ensures that when defining the tariff structure, after a clear justification of the principles of solidarity, the regulatory agency will allow the EPSA tariff structure to incorporate differentiated tariffs for different groups of customers trying to mitigate the economic efficiency losses. The subsidy and surcharge factors are determined by each EPSA with the approval of the regulatory agency. They are reflected in the tariff structure and emphasize the cross-subsidization scheme adopted by using distinct rates between customer categories and consumption blocks.

\subsubsection{Brazil}

Approximately $83.6 \%$ of Brazil's population has access to potable water. However, while urban areas have coverage of approximately 92\% [24], more than 6 million households in Brazil still lack access to safe drinking water. The sanitation situation is even more precarious because at the national level, the coverage rate for sanitation is only $53 \%$ of the population; in urban areas, it is $61 \%$, but only $40 \%$ of the total sanitation coverage in urban areas can be considered safe. When these rates are paired with the estimated population of 2015, the results show that more than 28 million people in Brazil do not have access to the sanitation system. The WSS tariffs in most Brazilian cities are based on IBT, generally with a minimum consumption previously set, usually $10 \mathrm{~m}^{3}$, and the cross subsidy between municipalities, customers and blocks is the main tariff subsidy model adopted. Social conditions and geographical areas are adopted as criteria for determining the level of benefits offered, in particular for the social tariff eligibility. In São Paulo, for example, the SABESP residential tariff has a minimum consumption of $10 \mathrm{~m}^{3}$ and four more blocks, with tariff increases that depend on the consumption. The subsidy for poor families is about $60 \%$ for the minimum consumption and the first block of 
consumption, reducing the subsidy as the consumption increases. The Brazilian tariff subsidy model will be later presented in detail in section four, which describes the Brazilian case study.

\subsubsection{Chile}

The WSS in Chile can serve as a reference for other areas in South America, as the drinking water supply service is almost universal, with coverage levels of $99.93 \%$. The coverage of wastewater collection is $97.17 \%$, of which $99.98 \%$ is treated. This implies that there are more than 5 million households with this service, benefiting approximately 17 million inhabitants. An important step for the progress of the WSS coverage was the review of the legal framework in 1988 that authorized the transition from the public ownership to the private ownership in the WSS. Currently, 53 WSS concessionaires are serving exclusive concession areas in 16 regions across Chile [25], and the current status-quo mostly reflects the organization and investments made in the sector in the first decade of the century. The two-part tariff prevails in Chile. In the company Águas Andinas, for example, the fixed tariff is unique and the variable tariff has two different prices, according to the peak or off-peak period of consumption. In some cases, a fixed monthly tariff is also charged for the fire service. The subsidy for drinking water and sanitation in 2018 benefited more than 683 thousand households, which corresponds to $12.4 \%$ of the country's urban customers and represents $4.9 \%$ of the sector's sales [25,26].

The subsidy model in Chile directly benefits low-income customers using state and municipality contributions of different percentages, depending on the socioeconomic level of each household, to cover the first cubic meters consumed. This benefit is deduced monthly and is indicated in the invoice because the beneficiary pays only the difference after the subsidy is applied. The municipality is responsible for the allocation and management of subsidies, including defining fixed tariffs and variable tariffs for sanitation based on the pollution load (DBO or other pollution indicator). Individuals or household groups that are unable to afford the full cost of their WSS can apply for a subsidy that takes their socioeconomic condition into account. To access the benefit, the customer must apply to the municipality and complete all the data in the registration form for the subsidy. For applicants who meet the requirements, the benefit begins one month after the one in which the grant decision is issued and can last up to 3 years if the same conditions are maintained. Later, the grant can be renewed. In addition, according to Law no. 19,949 of 2004, a social protection system called "Chile Solidario" is in place for households in extreme poverty; in this system, an additional benefit can be provided for WSS to cover $100 \%$ of the fixed and the first $15 \mathrm{~m}^{3}$ of consumption. The direct subsidy system provides greater accessibility for the poorest and most vulnerable households [27,28].

The Chilean model of direct demand-side subsidies, which has an explicit legal and regulatory framework with national coverage, is financed by general government funds and benefits customers from all regions. Indeed, direct subsidies offer an interesting contrast to indirect subsidies or crosssubsidization. In this way, the Chilean water subsidy model promotes better targeting of the benefit towards poor customers than other schemes found in developing countries [29].

\subsubsection{Colombia}

In recent years, Colombia has been able to provide more citizens with access to safe WSS. This achievement has contributed to overcoming poverty in the country by improving the living conditions of Colombians [30]. In Colombia, the water coverage is $97.4 \%$ in urban areas, $73.2 \%$ of the population has access to drinking water in rural areas, and the access to drinking water is $92.4 \%$ at the national level. Concerning the public sanitation service, there is $92.4 \%$ coverage in urban areas, $70.1 \%$ in rural areas and $88.2 \%$ at the national level [31]. In Colombia, as a rule, there is also a two-part tariff with a fixed and a variable component. The regulatory objective tries to carry out actions to extend WSS to poor households at affordable prices and with quality. Such an objective is fundamental for the economic development and the subsistence of a society [32]. 
The number of subsidies and surcharges in Colombia varies according to the social stratum. In accordance with the legal provisions, the Commission for the Regulation of Drinking Water and Basic Sanitation (Comisión de Regulación de Agua Potable y Saneamiento Básico-CRA), establishes subsidies for human consumption, set at 20 cubic meters per month per customer. There are 6 blocks of subsidy recipients consistent with the social-economic condition of the household. Stratum 1 applies subsidies of up to $70 \%$ of the cost of supplying basic consumption levels, stratum 2 applies $40 \%$ and stratum 3 applies up to $15 \%$, provided that the service coverage in the area is higher than $95 \%$. Customers in stratum 4, offices and special use buildings (public services, hospitals) are not subject to subsidies or overbilling. The maximum surcharge factor that can be applied to customers in strata 5 and 6 and for industrial and commercial customers is 1.20 . Only during the transition period or tariff readjustment can these percentages be higher, up to a limit of 50\% [33,34]. In Bogota, for example, the residential fixed tariff has a different price for each customer stratum and the residential variable tariff has a price per $\mathrm{m}^{3}$ for essential consumption and another price per $\mathrm{m}^{3}$ for non-essential consumption. The nonresidential customers only pay the fixed and variable costs by $\mathrm{m}^{3}$, according to their category.

\subsubsection{Paraguay}

In 2016, 95.3\% of the Paraguayan population had access to improved sources of drinking water, and $80.3 \%$ of the population had access to improved sanitation [35]. However, drinking water coverage by network at the national level is just $78 \%$ and sanitation coverage stands at a mere $11 \%$; from the latter, only $2 \%$ of the wastewater is treated [36]. Moreover, the last information available is more than a decade old, so the real numbers may be even smaller, given the natural growth of the population and the lack of important and successful investments to increase coverage in the last 10 years [37].

Additionally, in Paraguay, the current tariffs of the Paraguayan Water and Sanitation Services Company (Empresa de Servicios Sanitarios Del Paraguay-ESSAP) correspond to 3 categories of customers; (i) subsidized residential, (ii) non-subsidized residential and (iii) nonresidential. Each group has a fixed and a variable tariff with three consumption blocks. Compared to the regular residential category, the subsidized residential category pays $40 \%$ less on the fixed part of the tariff and $30 \%$ less on the variable part of the tariff. In practice, the ESSAP concessionaire applies a system of cross-subsidization, which consists of low-income customers paying less than the other customers. There is no national policy for the application of consumer subsidies to the poor or for making the service accessible; moreover, only a few providers, such as ESSAP, apply subsidies, and in other cases, low tariffs work as a universal and indiscriminate subsidy for the inhabitants with WSS [37] despite leading to their complete financial non-sustainability.

\subsubsection{Peru}

In Peru, in $2018,90.7 \%$ of the urban population had access to the water supply service, compared to $75.3 \%$ in the rural area. In the same year, $74.7 \%$ of the country's population had access to the public sanitation system, which equates to more than 24 million people. Sanitation coverage is higher in the urban area (88.9\%) than in the rural area (19.0\%) [38]. The subsidy model is set in law no. 30.045 of 2013 on the modernization of water and sanitation services where a system of cross-subsidization is designed to be applied to customers in situations of poverty and extreme poverty. National Superintendence of Sanitation Services (Superintendencia Nacional de Servicios de Saneamiento-SUNASS) is responsible for the supervision and its implementation. Fixed and variable tariff is the most used tariff structure in the country; however, the variable part of the tariff follows the IBT scheme. In Lima, for example, SEDAPAL adopts a uniform fixed tariff for all the customers and a variable tariff which is different for residential and nonresidential customers, with several blocks. The WSS increase depends on the consumption. 
Until 2016, the cross-subsidy was directed to families consistent with the basis of the Family Segmentation System (Sistema de Focalización de Hogares-SISFOH). However, due to the limitations in the use of SISFOH in the efficient allocation of cross-subsidies, Stratified Plans started to be used, prepared by the National Institute of Statistics and Information Technology-INEI, as it is an instrument that allows identifying the locations of the city where the largest amount of population is living in poverty. The extracts are classified into 5 levels according to the per capita family income (i) low, (ii) medium low, (iii) medium, (iv) medium high and (v) high. In 2016, customers in the lower-income residential category were grouped into a new subcategory called subsidized residential, which accounted for 33\% of all home customers in Lima and Callao [39]. The difference in income for each city causes differences that translate into uneven coverage levels; metropolitan areas have greater WSS access coverage, while low-income municipalities have a much lower service coverage rate [40]. There has been significant progress in Peru in increasing access to WSS. Despite these improvements, inequalities in access persist, and it is important that future efforts focus on the subsectors of the Peruvian population to universalize access for the poorest households [41].

\subsubsection{Uruguay}

Compared to other countries in the region, Uruguay stands at a very good position. In 2015, Uruguay was the Latin American country with one of the highest percentages of access to an improved water source, followed by Argentina, Chile, Brazil, Costa Rica and Paraguay [42], but it has since then been overtaken by Chile. There was excellent access to drinking water throughout the country in 2016, with $99.8 \%$ for Montevideo, $98.8 \%$ for localities with more than 5000 inhabitants and $72 \%$ in smaller and rural localities; regarding water provision at the national level, $98.4 \%$ of the population had an improved water source inside or outside home, and $96 \%$ had access to piped drinking water $[43,44]$. Concerning sanitation coverage, in $2018,43 \%$ of the population had access to sanitation networks and adequate treatment, meaning at least 1,524,500 inhabitants [45].

There is a social fee to help low-income sectors and those who live in irregular settlements access to WSS. Subsidies for consumption of 10 to $15 \mathrm{~m}^{3}$ and bonuses are granted, as appropriate. The OSE (Obras Sanitarias del Estado), the single water supply operator of the country, has instituted a cheaper price for people who have financial difficulty in accessing WSS. Customers must meet the requirements defined by the Ministry of Social Development, and everyone included in the programs can apply for this benefit. Households identified by the National Housing Directorate as being in a situation of socioeconomic vulnerability also receive this benefit. The subsidy and social bonus amounts are approved annually by a decree from the executive branch with guidance from the regulator (Unidad Reguladora Servicios de Energia y Agua-URSEA). The components of the tariff for drinking water services are divided into two parts, fixed charges and variable charges (according to the consumption block). The sanitation services maintain the same format of fixed and variable tariffs, which are equivalent to $100 \%$ of the invoice amount for water consumption [46]. There is cross-subsidization between residential and nonresidential customers. The OSE tariff in Uruguay has a fixed part defined according to the diameter of the connection and a variable part consistent with the consumption block. However, for a consumption of up to $10 \mathrm{~m}^{3}$, the variable tariff is fixed per month, i.e., it defines a minimum consumption and, above this minimum level, the price per $\mathrm{m}^{3}$ increases in line with the consumption block.

\subsection{Subsidy Model, Tariff Structure and Coverage by Country}

In most Latin American countries, the tariff structure has different categories of customers: (a) residential customers and (b) nonresidential customers. Nonresidential customers are usually divided into three groups: (i) commercial, (ii) industrial and (iii) public institutions. In the case of residential tariffs, the categorization system varies widely according to different geographical areas and social groups [47]. 
In most cases, the tariff structure used contains a sequence of incremental consumption blocks (IBT). In theory, the first residential consumption block offers a reduced rate and should be limited to basic subsistence needs (lifeline tariff). The rate becomes higher, as consumption increases. In general, the tariff rise respects the paying consumer principle where the consumption of a finite good beyond basic needs has higher a price per cubic meter than average. In some countries, compared to the lower residential consumption blocks, the incremental price for the higher consumption blocks does not show large variations in the price per cubic meter, and control mechanisms to limit unnecessary consumption are not promoted. Nonresidential categories sometimes have an inverted consumption block price sequence; in the first consumption blocks, the price per cubic meter is higher than the residential price, and as the consumption block increases, the price per cubic meter decreases, tending to move towards the average price. This situation is explained because nonresidential customers have high consumption rates, as they use water as part of their manufacturing process, commercial activity or public service.

Table 1 summarizes the existence of regulation, the predominant tariff structure model, the tariff subsidy model adopted, the population and Gross Domestic Product (GDP) per capita, both according to the World Bank, and also provides general information on coverage of access to WSS in each country analyzed. However, the absolute values do not effectively represent water and sanitation coverage by water distribution and sanitation collection networks.

In South America, only Chile promotes a direct demand-side subsidy policy for residential water and sanitation customers not using indirect subsidies or cross-subsidization without burdening other customers or service providers. In Argentina and Colombia, some direct subsidy practices can be identified, but the cross-subsidization model is predominant, as it is in other countries. Tariff subsidy policies for poor and vulnerable customers can have infinite rules. Benefits can be attributed based on geographic area, household income, or type of house in order to meet the intended purposes. In section three, a categorization of the main subsidy models will be discussed.

Note that Table 1 characterized the subsidy models in South American countries for the urban WSS and rural WSS, which are endowed with conventional water networks (abstraction, water treatment plan and network distribution). The population in most rural systems is set in the jungle, mountain or very sparse areas and makes use of individual or communal systems, staying out of those schemes. Even when they have piped network, in general, they are simplified systems with a treatment point (chlorination). Furthermore, these rural systems frequently encompass the poorest and most vulnerable people. However, some of the countries have developed sound and relatively effective solutions as SISAR (Sistema Integrado de Saneamento Rural) in Brazil, JASS (Juntas Administradoras de Servicios de Saneamiento) in Peru or CAPS (Comités de Águas Potables y Saneamiento) in Bolivia. There, the cost recovery is more difficult or impossible to achieve; they are not appealing for the private sector, and governance issues are determinant. The objective of this research was not to discuss the access in these non-piped or non-conventional piped systems, which, certainly, is a limitation of the study and deserves a specific study for that purpose. 
Table 1. Subsidy model and coverage for water and sanitation services (WSS) by South American country.

\begin{tabular}{|c|c|c|c|c|c|c|c|c|c|c|}
\hline Country & Regulation & Tariff Structure & $\begin{array}{l}\text { Cross } \\
\text { Subsidies }\end{array}$ & $\begin{array}{l}\text { Indirect } \\
\text { Subsidies }\end{array}$ & $\begin{array}{l}\text { Direct } \\
\text { Subsidies }\end{array}$ & $\begin{array}{l}\text { Subsidy Targeting } \\
\text { Scheme }\end{array}$ & $\begin{array}{l}\text { Population } \\
2018 \text { Word } \\
\text { Bank }\end{array}$ & $\begin{array}{l}\text { GDP per Capita } \\
2018 \text { (US\$) } \\
\text { Word Bank }\end{array}$ & $\begin{array}{c}\text { Water } \\
\text { Access } \\
\text { Coverage }\end{array}$ & $\begin{array}{l}\text { Sanitation } \\
\text { Access } \\
\text { Coverage }\end{array}$ \\
\hline Argentina & Yes & Fixed and variable & Yes & Yes & Partial & $\begin{array}{l}\text { By zone, quality of } \\
\text { housing, and year } \\
\text { of construction }\end{array}$ & $44,494,502$ & 11,684 & $84.4 \%$ & $58.4 \%$ \\
\hline Bolivia & Yes & $\begin{array}{l}\text { Fixed and variable } \\
\text { with IBT }\end{array}$ & Yes & Yes & No & $\begin{array}{l}\text { By geographical } \\
\text { area }\end{array}$ & $11,353,142$ & 3549 & $85.6 \%$ & $59.2 \%$ \\
\hline Brazil & Yes & $\begin{array}{l}\text { Minimum } \\
\text { consumption and IBT }\end{array}$ & Yes & Yes & No & $\begin{array}{l}\text { By social conditions } \\
\text { and geographical } \\
\text { area }\end{array}$ & $209,469,333$ & 8921 & $83.6 \%$ & $53 \%$ \\
\hline Chile & Yes & Fixed and variable & No & Yes & Yes & For family income & $18,729,160$ & 15,923 & $100 \%$ & $96.8 \%$ \\
\hline Colombia & Yes & Fixed and variable & Yes & Yes & Partial & $\begin{array}{l}\text { By geographical } \\
\text { area and based on } \\
\text { housing quality }\end{array}$ & $49,648,685$ & 6668 & $91.4 \%$ & $69 \%$ \\
\hline Paraguay & Yes & $\begin{array}{l}\text { Fixed and variable } \\
\text { with IBT }\end{array}$ & Yes & Yes & No & Type of housing & $6,956,071$ & 5822 & $95.3 \%$ & $80.3 \%$ \\
\hline Peru & Yes & $\begin{array}{l}\text { Fixed and variable } \\
\text { with IBT }\end{array}$ & Yes & Yes & No & $\begin{array}{l}\text { By geographical } \\
\text { area }\end{array}$ & $31,989,256$ & 6941 & $90.7 \%$ & $74.7 \%$ \\
\hline Uruguay & Yes & $\begin{array}{l}\text { Fixed and variable } \\
\text { with Minimum } \\
\text { consumption and IBT }\end{array}$ & Yes & Yes & No & $\begin{array}{c}\text { By social conditions } \\
\text { and geographical } \\
\text { area }\end{array}$ & $3,449,299$ & 17,278 & $99.8 \%$ & $99.5 \%$ \\
\hline
\end{tabular}

Sources: Argentina [14]; Bolivia [21]; Brazil [24]; Chile [25]; Colombia [31]; Paraguay [35]; Peru [38]; Uruguay [43,44]. 


\section{Categorization of Subsidy Models for WSS Tariffs}

\subsection{Overview}

Subsidies are an economic instrument that aims to encourage the consumption or production of goods and services and basically consists of the difference between the real price and what is actually spent to make consumption or production effective. In general, the application of specific subsidies, both for consumption and for production, derives from the public authority's objective of achieving certain social goals or favoring specific groups to create economic instruments of social policy to guarantee universal access to WSS, especially for low-income and vulnerable populations and localities. Subsidies to the supply side are defined as stimuli or resources granted to producers of goods and services, and subsidies to the customer demand side aim to expand and provide access to a particular good or service [48]. It is questionable whether social aspects should be borne directly by other customers or indirectly by the public budget of the State paid by all taxpayers, especially if the services are provided to different types of customers [49].

Subsidies to the supply side through resources for investment are intended to help achieve the coverage goals. In general, they are awarded to non-taxable funds or resources and are financed by the federal, state or municipal public budget, that is, resources from public sources. Investments funded by these sources of funds do not require returns, are not included in the asset base used for the calculation of tariffs and do not generate capital costs in terms of asset depreciation and compensation, so these tariffs tend to be lower than those derived from indebtedness, thus contributing to their ability to broaden access to low-income customers and provide end-customer service. Another supply-side subsidy may be through financing with lower than market interest rates or subsidized interest rates for costly investments.

Subsidies to the demand side aim to help achieve the effective access to WSS by the customers. Granting quantities $\left(\mathrm{m}^{3}\right)$ or financial resources to the poor population to allow them having WSS available are examples of these subsidies. While subsidies to supply are more related to deployment of infrastructure and physical access to WSS, subsidies to demand are more associated with the economic access to WSS by the customers. Although subsidies to supply are required to increase the WSS coverage, in low and medium income countries, usually they are not enough and demand-side subsidies are also needed.

\subsection{Categorization}

To ensure the access to WSS for poor and vulnerable households, the provision of these services requires some form of subsidy, which may be (i) governmental or philanthropic, (ii) cross-subsidization among other customers or (iii) cross-subsidization among other sectors or ways. These subsidies may still be allocated on the demand or supply side, having different functions, and in some cases, the subsidy for these services may be intergenerational, so that one generation pays for the investments that will benefit another generation. Subsidies for WSS have two main characteristics, in particular, expanding access or increasing consumption, and when they are misdirected, the expected effects are not attained, so transparency and clarity on targeting should increase the expected benefit of subsidies. Another way of assigning subsidies for WSS tariffs is by doing it implicitly, that is, when tariffs are applied for everyone, or explicitly, when some sort of segmentation is involved. This segmentation implies selection criteria that can be automatic when there are different categories of services or distinct pricing structures or administrative selection that consists of the categorization of customers who will have access to the subsidy through a process with observable variables. Finally, the subsidy can be direct, when income is able to be observed for destination criteria, or indirect, in situations in which certain variables can be considered (geographical location, quality of housing, among others) [50-52]. Figure 1 lists the different models of subsidies and the possible coordination of public policies aimed at universal access to WSS. 


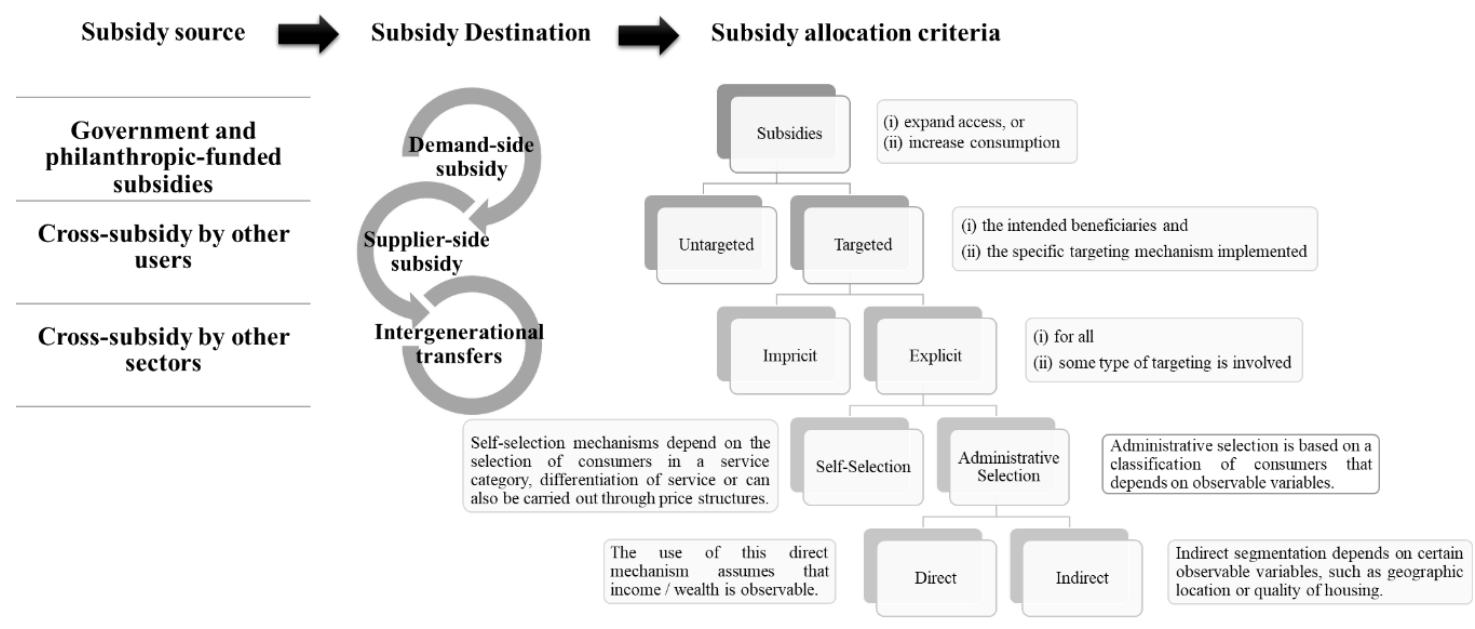

Figure 1. Categorization of the main water and sanitation subsidy models. (Adapted from [50]).

To promote the expansion of the supply, governments develop public policies aimed at universal access to WSS. For example, they provide tax benefits to providers, who can receive subsidies such as tax exemptions for the acquisition of customer goods and income taxes, and in this way, they end up benefiting customers who are socially vulnerable, thus creating an indirect subsidy for the supply. Tax subsidies are public tax exemptions levied directly on the tariff revenue collected by the service provider and can also be granted to the operation concerning the commercialization of customer goods inherent to the production. This subsidy model should be a public policy that aims to expand WSS delivery and allows a restructuring of the service provider to develop actions that increase customers' access to WSS and to offer these services at affordable prices to the poorest and most vulnerable customers.

Direct subsidies to public infrastructure services are very common both in developing and developed countries. The transfer of resources for the construction of water and sanitation systems through the public budget and subsidized credit operations help expand the service coverage. Direct investment (supply) subsidies are used to increase service attendance and do not always benefit customers in the social sphere. Direct investment subsidies are often applied in places with a high population density where there is no installed infrastructure, which allows a greater increase in coverage but does not always promote equal access to WSS.

Demand subsidies are classified into two categories: direct or indirect. Direct subsidies occur when the burden of price cuts falls on the government. In the WSS sector, the government can both subsidize the demand side for the household connection and also help pay part of the costs of the service provided to some customers, especially as a discount in the normal price reflected in the invoice to indicate who pays and what the basis for the calculation is. Cross-subsidization can be direct or indirect so that the subsidy will not reach the entire sector and the government will not incur any cost to grant it, but the utility calculates the tariff needed to cover the total costs. However, the price charged to customers is heterogeneous, varying according to the tariff structure. In this model, some customers tend to pay more than the effective cost of the service to allow others having the same access to the same service at a lower price. These subsidies can be awarded through a single tariff structure without necessarily benefiting specific customers and without the need to register household characteristics and are non-targeted subsidies. Price targeting may require households to meet certain attributes in order to allocate subsidies only to poor families who are socially vulnerable and that are the target of the subsidies.

\subsection{Discussion}

The predominant tariff subsidy policy in South America, with the exception of Chile, is based on the cross-subsidization model that adopts distinct paths and can be expressed differently within countries. 
Price discrimination can be classified into two main groups: in the first group, the socioeconomic characteristics of residential customers or the activity of nonresidential customers are used as references; in the second group, the distinction is made through consumption levels. In practice, the two models are non-exclusive and applied simultaneously. Given the level of poverty and inequality in the distribution of income found in countries with medium and low levels of income, the use of subsidies as an economic instrument has become generalized, and several forms of granting the benefit, which have somehow had a positive effect, have appeared. However, the effectiveness of the models generates pertinent questions because the subsidies may end up being directed to those who do not need social benefits.

In subsidies for the demand side, the direct payment of the basic consumption invoice for customers who fulfill certain socioeconomic criteria assures low costs relative to the income of poor households and does not burden the service provider or other customers. Moreover, the cross-subsidization model used in the tariff structure with IBT with reduced tariffs is applicable to groups of customers who fulfill certain socioeconomic criteria, known as social tariffs. There may be some inversion of values in the cross-subsidization model when prices in the tariff structure and IBT carry tariff values lower than the average tariff in the first blocks and are applied to all customers; in such cases, the actual expected effect of the cross-subsidization model might not be reflected.

In South American countries, generalized subsidies for residential customers are present in most WSS. One of the main goals of the subsidy is to make or keep the service accessible to low-income households, especially when rates increase to levels commensurate with full cost recovery. From this point of view, direct subsidies have advantages due to their transparency, formality and non-distortion in the behavior of WSS and their customers. Their main disadvantages are the higher administrative costs and the difficulty in designing adequate eligibility criteria [48]. The urban tariff subsidy should be restricted only to low-income residential customers, and subsidized consumption should be limited to a minimum volume per month per customer, a volume that is considered adequate to meet the needs of a typical household. The purpose of this measure is to prevent superfluous consumption and potential transfers to non-beneficiary customers. The share of subsidized consumption is variable and depends mainly on the socioeconomic level of the customer and the price level of the WSS in each region. The subsidy that is granted should be selective, of a short and predetermined duration and unable to be renewed automatically. In this way, after a certain period, the applicant must repeat the registration steps to reapply for the benefit. The reason for this is to enforce the periodic review of applicants so as not to generate perpetual benefits that are usually only maintained by the inertia of public administration.

Furthermore, as emphasized before, this research discusses the subsidy policy only for the conventional or urban piped systems. The challenge and complexity of the rural areas where deployment of network is simplified or not predicted is much greater. Besides frequently involving a more fragile population, governance issues, including information, education, communication and communal leadership, are very relevant.

\section{The Case of Brazil: Proposal for Improvement}

In Brazil, the Federal Law no. 11,445 of 2007 establishes in its second article that subsidies are economic instruments of social policy used to guarantee universal access to WSS, especially for low-income populations and localities. According to article 31 of the law, subsidies are classified as I-direct when intended for specific customers or indirect when aimed at the service provider; II-tariffs when they integrate the tariff structure or fiscal when they are derived from the allocation of budgetary resources, including subsidies and III-internal to each owner or exist between localities, as in the cases of associated management and regional provision. 


\subsection{Households without Access to WSS}

According to the latest Brazilian census [53], the WSS deficit is concentrated in households with minimum income brackets. There were almost 4 million households in urban areas and approximately 6 million more in rural areas without access to the piped water supply. Approximately $70 \%$ of the urban households that did not have access to the piped water supply were households earning up to three times the minimum wage per month (U\$ 410). As for the sanitation service, the number of households without access to sewerage or septic tanks reached approximately 12 million in the urban area, and $76 \%$ of those households had an income level of up to three times the minimum wage, representing more than 9 million residences. In rural areas, more than 6 million households do not have access to these systems, and $89 \%$ of these properties correspond to the population with an income of up to three times the minimum wage. The distribution of households without access to WSS is shown in Figure 2.

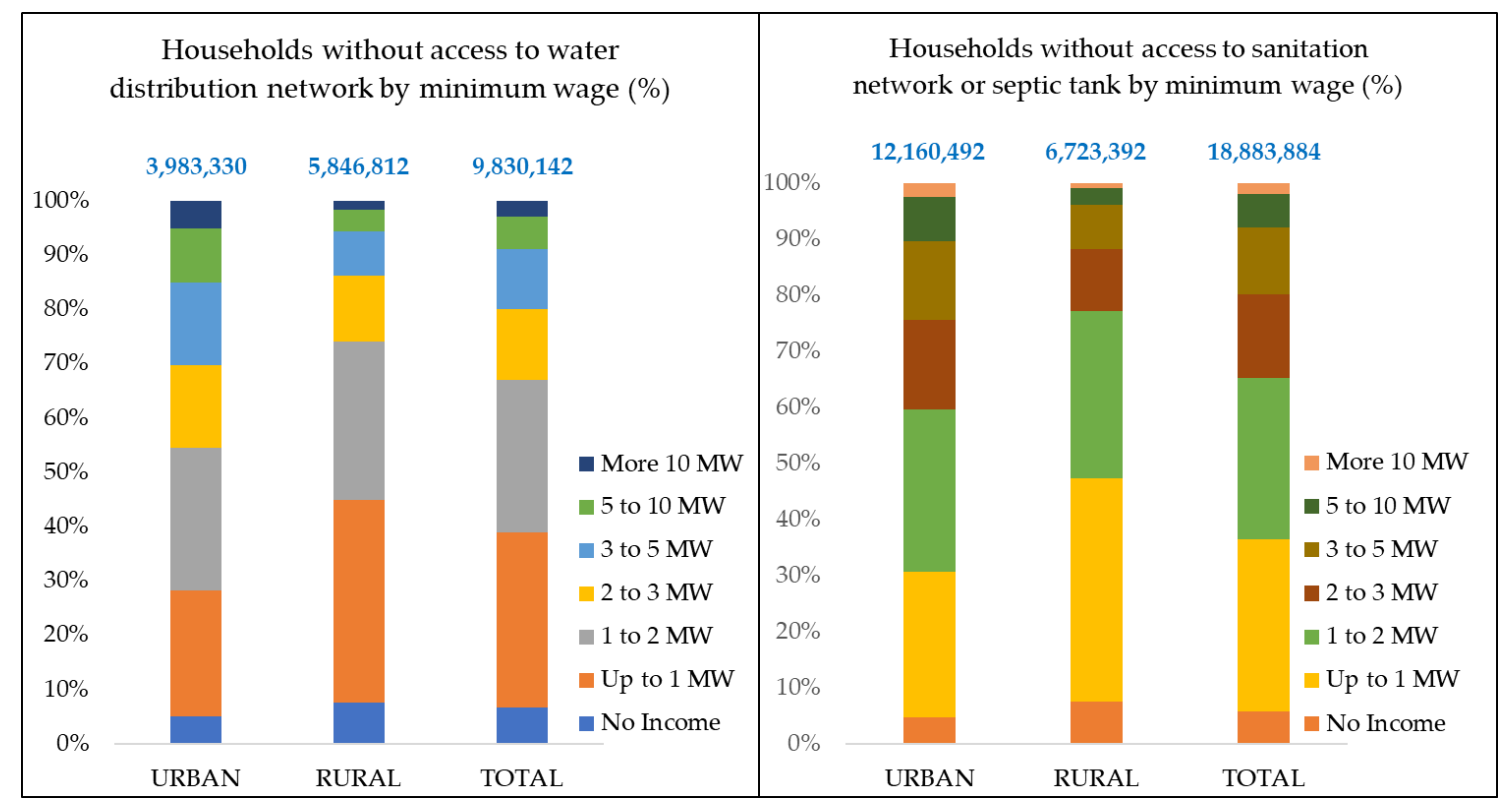

Figure 2. Deficit of WSS by household income brackets.

The problems of sustainability and governance that accompany the development of societies lead to the existence of very serious social problems in the slums and peri-urban areas of large cities. Hence, high investments are needed to reach universal WSS in these areas of social vulnerability [54]. In addition, projects in vulnerable areas are very complex and require different individual solutions for each situation $[55,56]$. Better governance and innovative contracting models for WSS are needed for areas of social vulnerability involving the various actors, including the private sector through public-private partnerships (PPPs) or other public partners or the community directly or through public-public partnerships (PUPs). For these partnerships or the communal solutions to be sustainable, they must be based on sound governance principles, take into account the vulnerability of the communities involved and include subsidiary, transparent, proportionate and responsible solutions [57].

\subsection{Tariff Subsidies for WSS}

The tariff structure should provide for the set of rules and procedures that determine how to charge different categories of customers [58]. In Brazil, residential customers can be classified into two categories: regular residential and social residential. Most of the tariff structures analyzed contain this subdivision for residential customers, so that the social tariff, both fixed and volumetric (IBT), are lower than the regular tariff, characterizing the cross-subsidy for the poorest families. From this perspective, 27 tariff structures used throughout the Brazilian territory by the various regional WSS 
(which are state-owned enterprises-SOE) were analyzed to identify the subsidy intensity granted to poor households according to the official publications of each entity surveyed. This corresponds to more than $75 \%$ of the Brazilian population.

The percentage of subsidies granted by each regional $\mathrm{SOE}$ varies in different regions of the country. Ten providers have a variation of up to $50 \%$ between their regular and subsidized residential prices, while the remaining seventeen providers offer a reduction of more than $50 \%$ for the subsidized price. The SOE with the most differentiated social tariffs are from the state of Santa Catarina, which grants $81 \%$ of subsidies to customers in the social residential category, followed by the state of Rio Grande do Norte $(80 \%)$ and Pernambuco (79\%). The state of Rio de Janeiro (by its SOE CEDAE) offers only a $12 \%$ subsidy for this category. Figure 3 below presents the percentage of subsidies granted to customers belonging to the social residential category in comparison to the regular residential category for each of the tariff structures analyzed.

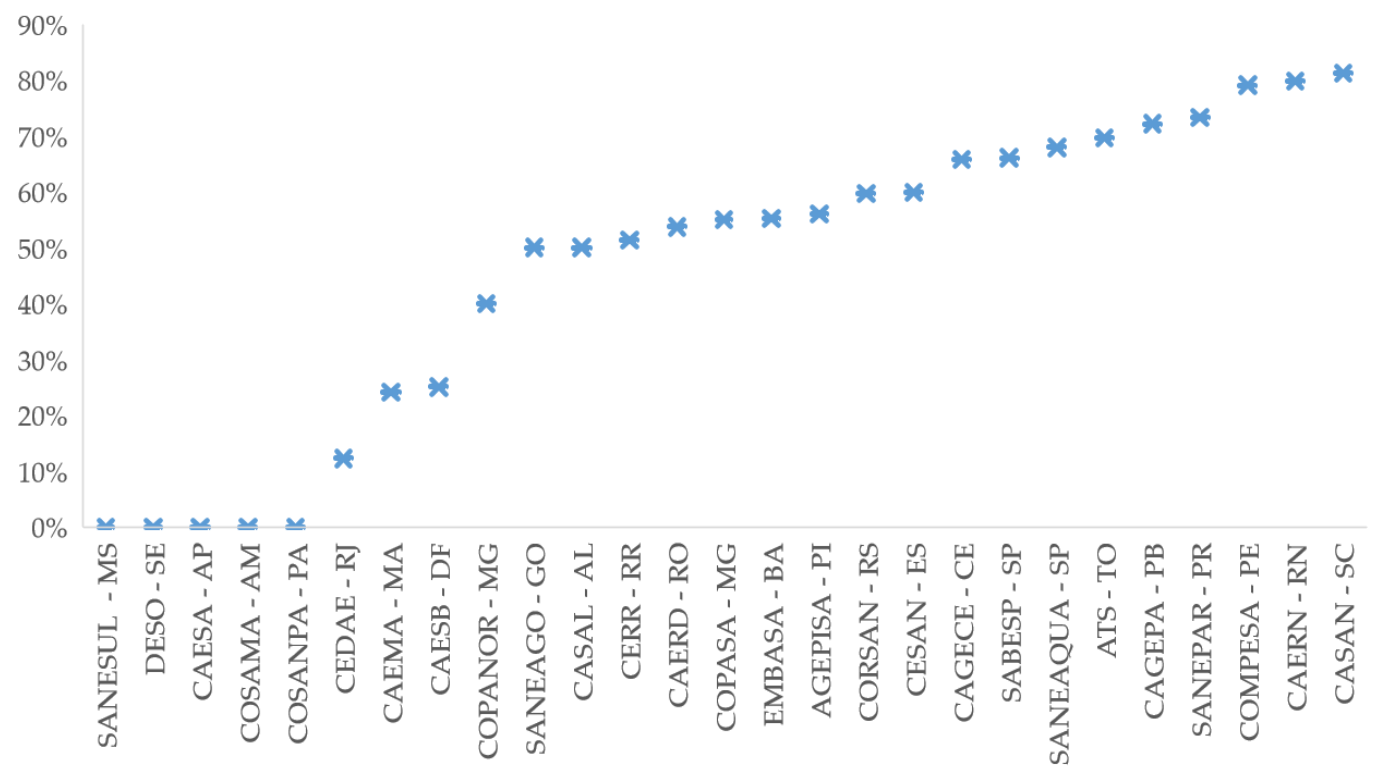

Figure 3. Social residential tariff category versus regular residential tariff in the Brazilian SOE.

The cost of water is another potential barrier that should be considered; the poor usually pay more per liter of water, even if the quality of service and the drinking water quality provided are worse. It turns out that households living in slums and peri-urban areas sometimes pay more per liter of water than households with connections [59]. According to the United Nations, access to WSS must be available and accessible to all, even the poorest residents. The costs of WSS should not exceed $5 \%$ of household income, meaning that services should not affect people's ability to purchase other essential goods and services, including food, housing, health services and education [60].

The charges per household income for WSS can be determined taking into account the cost in each region of Brazil. Per capita household income in the country is displayed by IBGE (Statistics Brazilian Institute) for each year and is calculated as the ratio of total household income to total residents of each household. To identify the household income expenditure on these services in Brazil in 2018, the price charged for WSS by the SOE in the different regions of the country for $10 \mathrm{~m}^{3}$ in relation to the per capita household income was calculated. This amount $\left(10 \mathrm{~m}^{3}\right)$ was considered since it is near of the average consumption of Brazilian households, corresponding also to the minimum consumption in Brazil and to the measure more internationally used for comparison purpose.

The first calculation verifies the burden of the water charges relative to the per capita household income for regular residential and social residential water customers, while the second one includes also expenditures on sanitation services for the same two consumption categories. 
Figure 4 shows the result of the per capita household income charges in relation to two trend lines: (i) $3 \%$ and (ii) 5\% in two different analyses, respectively: (a) water expenditure to $10 \mathrm{~m}^{3}$ and (b) water and sanitation expenditure to $10 \mathrm{~m}^{3}$. Of the 26 regional SOE analyzed (the District Federal (Brasilia Capital) WSS of CAESB was here removed since it is a particular case of high income), per capita household income expenditure above 3\% occurs in twelve SOE for the regular residential water customers, and only one exceeds $5 \%$, while in the social residential water price, only two SOE charge more than $3 \%$ of the per capita household income. When the price of sanitation is included, the per capita household income charges increase, and for the same group, twenty-two SOE for the regular residential customers display a burden with the water and sanitation services above 3\%, while sixteen of them go beyond 5\%. For the social residential customers, the burden with the water and sanitation services from ten SOE is above 3\%, and only in three cases, it is above 5\%. Note that the analysis is carried out for the average, meaning that the charges for the lower quartiles of income reach higher values that are unaffordable. Unfortunately, the information by quartiles is not available.
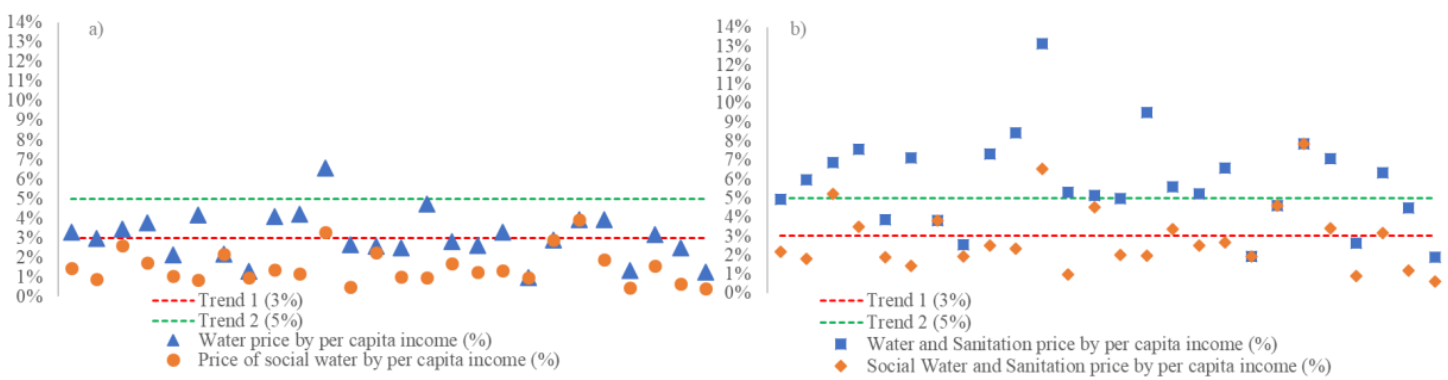

Figure 4. Burden with the (a) water and (b) water and sanitation services for the social and regular residential customers for a consumption of $10 \mathrm{~m}^{3}$.

Besides the subsidies that are randomly granted to the supply (investments in infrastructure to increase the coverage) in Brazil, the tariff subsidy is applied differently between (i) categories of consumption, with the commercial, public and industrial categories financing the lower residential blocks; (ii) consumption blocks, with a higher consumption of cubic meters of water or higher amount of wastewater collected having a higher cost; and (iii) between regions, with the metropolitan regions, for example, subsidizing most of the rural municipalities in each states based on the scale efficiency. This last case is genuine cross-subsidization, since it takes place between municipalities, while the first two happens internally within municipalities [61]. In fact, the cross-subsidization model practiced in Brazil is not a mere subsidy for poor households, but currently, it also includes transfer between municipalities, through revenue sharing, which is socially and financially unsustainable. This situation jeopardizes the investment plans of SOE and municipalities and, consequently, the achievement of the universal access for all WSS customers in the short and long term so that the corrosion of investment capacity puts both the expansion of water supply systems and the implementation of wastewater collection and treatment systems at risk. According to UNESCO, where access is still a problem, it is preferable to support those who are unable to pay rather than lower the price of water for everyone, mainly because this policy may benefit only the richest rather than contribute to the universal access to the service [62].

In Brazil, there are no specific subsidy rules relative to WSS, mainly as regards the economic and financial aspects of regulation. It is the responsibility of the regulatory agencies to develop more specific rules concerning tariffs, subsidies and regulatory accounting. This is a consequence of the slow progress in the economic regulation of the sector compared to that in the technical (quality of service) regulation [63]. Thus, it is necessary to make progress concerning the norms of these services, with an emphasis on universal access to WSS, in order to establish feasible price criteria that assure the sustainability of the service provision and reasonable prices for all categories and blocks of consumption and covering the targets contained in the Municipal Basic Sanitation Plans (PMSB). 
In this way, linking public policies and regulation allows resources to be concentrated and directed towards universal access to WSS, subsidies to be responsibly allocated to supply and demand and investments to be prioritized for WSS for poor and vulnerable households, thus increasing access without jeopardizing such households' ability to pay.

The selection criteria for access to the demand-side subsidy should have clear rules for the choice of the beneficiaries, as well as for the allocation of the amount of subsidy according to poverty and income levels. In the state of Santa Catarina in southern Brazil, the regional SOE (Casan) grants a differentiated rate called "social tariff", in which approximately 7000 households are given benefits and charged a special price. To access this benefit, the household must be in a dwelling of up to $70 \mathrm{~m}^{2}$ in an area constructed for residential purposes, have a per capita household income of up to half the minimum wage and must not own a car. In the state of Minas Gerais in southeastern Brazil, article 4 of Resolution of ARSAE (regulatory agency of the Minas Gerais State) no. 111 of 2018 includes eligibility criteria for the social tariff where the subsidy is only granted to the residential unit, the residents must belong to a household enrolled in the Single Registry for Social Programs of the Federal Government (CadÚnico), and the monthly household per capita income of the residential unit must be less than or equal to half of the national minimum wage. The SOE (Copasa) must update the information about the beneficiaries of the social tariff at least once a year. In the state of São Paulo, the regional SOE (Sabesp) grants tariff benefits to households with monthly incomes of up to three times the minimum wage living in informal settlements (wood or masonry, rustic houses) with a constructed area of up to $60 \mathrm{~m}^{2}$ and being a single-phase consumer of electricity with a consumption level of up to $170 \mathrm{Kw}$ per month, those living in collective, low-income households (tenants and the like), or unemployed people whose last salary was a maximum of three times the minimum wage. The registration for the social tariff is valid for a period of 24 months, and after this period, the customer must prove his or her situation of social vulnerability again.

\subsection{Proposal for Improving the Tariff Subsidy Policy in Brazil}

Brazil is the fifth largest country in the world in terms of territorial extension, with 26 states and a federal district formed by more than five and a half thousand municipalities. Each municipality is responsible for its own local water and sanitation policy in both urban and rural areas which is included in its PMSB. Only 6\% of these municipalities have more than a hundred thousand people, reducing the effects of economies of scale and scope and making cross-subsidy policies for WSS tariffs unfeasible. Cross-subsidization has a threshold, and the income pattern in Brazil in certain cases makes it possible to have cross-subsidization between similar municipalities, but this can hardly happen between the small number of rich municipalities and the large number of poor municipalities. Therefore, even deploying public financial resources to make investments and increase the WSS coverage, Brazil should opt for a direct demand-side subsidy policy and review the current tariff structure based on IBT. This should be firstly financed at the federal level of government even though the municipalities are the ones responsible for the eligibility process of the households. The national law can define very clear basic criteria for selecting eligible households to receive subsidies, and the tariff blocks number and size must be small. The percentage of subsidies established in each tariff block should be defined by each regulatory agency, along with specific conditions and the criteria to be considered for the extreme poverty block. The size of the blocks depends on the household size and the per capita consumption, both of which change substantially across the country. Financial resources can come from the federal, state or municipal government and from WSS funds. IBGE data show that, on average, in Brazil, there are 3.3 people per household [53]. According to the World Health Organization (WHO), between 50 and 100 L of water per person per day are needed to ensure that the most basic needs are fulfilled. Thus, it is estimated that an average household should consume between $5 \mathrm{~m}^{3}$ and $10 \mathrm{~m}^{3}$ per month. Therefore, tariff subsidies must be granted to poor households in small blocks of tariff increases at a maximum of $10 \mathrm{~m}^{3}$ to guarantee the universal human right to WSS. Extreme cases must be defined by the appropriate regulatory agency, which must define criteria for 
connection and price subsidies, to establish subsidy levels that vary according to the income condition of each household to meet the most variable situations. These criteria should establish the threshold for the volume to be subsidized with small price increase blocks in each benefit range, for example, total subsidy, $70 \%, 40 \%$, and 10\% successively in order to cover all situations attributed to socially vulnerable households.

In cases where cross-subsidization is economically and financially viable to be enough, it is necessary to revise the tariff structure to identify possible deficiencies for each type of customer and each block of consumption so that social benefits will not be granted to customers who do not need subsidies, ensuring revenue sufficiency, revenue stability, economic efficiency, equity and fairness in cost allocation [64]. The price should reflect the cost of production to residential customers in the first blocks and define rules for price increases for each water consumption block based on the rule of the customer payment principle and on polluter payment principle as to the generation of wastewater. Other types of customers, particularly commercial and industrial customers, should pay higher tariffs that are intended to finance the social residential blocks. As they have more affordability and willingness to pay, the contribution of these customers helps the effectiveness of the cross-subsidization scheme, and in several countries (moderate or high rent), it is enough to avoid direct demand-side subsidies. However, in Brazil, they are not enough even though this is an important contribution to reduce the amount of the direct subsidy to be paid. The maximum impact of cross-subsidization taking into account the households' income was simulated, and the affordability would overcome substantially the recommendable values between 3 and $5 \%$. The interval between each consumption block should be neither too large nor too small, and increasing the price for blocks for every 5 to $10 \mathrm{~m}^{3}$ of consumption allows a better allocation of the distributive tariff criteria. The arrangement of the tariff structure of WSS must provide financial resources that enable the provider not to grant large subsidies for the demand from poor households. This should be done with a good quality of service that reaches the universal service goals provided for in the PMSB and in coordination with other public policies that aim to promote investment through non-refundable resources or subsidized financing to keep the level of social welfare high. The cross-subsidization between different localities must be fully controlled, with specific accounting that will allow each municipality to understand the real financial situation of its WSS.

The bill currently being drafted by the Chamber of Deputies in Brazil to "Create the Social Water and Sanitation Tariff" proposes as a single criterion for the household to qualify as a beneficiary, corresponding to a per capita income of up to half the minimum wage. The social tariff would be cumulatively calculated: there would be a $40 \%$ discount for consumption up to $10 \mathrm{~m}^{3}$ per month, $30 \%$ for consumption above 10 and up to $15 \mathrm{~m}^{3}$ per month and a $20 \%$ discount for consumption of 15 to $20 \mathrm{~m}^{3}$ per month. There would be no discount for consumption exceeding $20 \mathrm{~m}^{3}$ per month [65]. However, this proposal does not define the subsidy model or a source of funds for these subsidies, as, once again, the cross-subsidization policy will be used. As a result of this proposal, the implementation of control mechanisms is necessary, since any change in the consumption block or the profile of a tariff structure may jeopardize the economic and financial balance of the service provision, which will result in extraordinary tariff reviews. The economic and financial balance of WSS needs to be maintained, as well as households' ability to pay. Therefore, politicians must concentrate their efforts on approving a solid national policy that ensures the provider the recovery of established subsidies. In this case, the direct demand-side subsidy might be the most efficient option; it is applied with clear rules for blocks with determined tariff increments that are easily identified by accounting and benefit the poor without putting customers or providers at risk.

Indeed, the new reform continues to believe that the economic and financial equation closes just with the level and tariff structure and, in our view, this will be not possible without direct demand-side subsidies even though the direct subsidies to supply (investments) continue to take place. A major problem is that government refuses to face the real problem, which is the unavoidable lack of affordability Brazilian people in general face in paying the bill without jeopardizing other basics 
expenses (food, housing, etc.). Due to the large number of poor people in the country, this cannot be solved with any cross-subsidization scheme although obviously, it helps and should also be used to its maximum potential. Even though, as highlighted, it is not enough.

\section{Conclusions}

This research discusses the main policies used to universalize access to WSS, contextualizing the way subsidies are granted in South American countries. The investigations carried out in these countries point to diverse experiences in this region and provide interesting lessons on tariff subsidies for poor customers. This article develops and focuses particularly on the case study of Brazil. The reality of this country is detailed and discussed, and the content of the ongoing water regulatory framework reform is criticized. A new subsidization model is proposed, including several suggestions and recommendations to improve the status-quo.

Current indirect subsidy and cross-subsidization policies are important, but best practices to expand access for poor residents require direct demand-side subsidies. Poor households usually live in areas of high vulnerability with different access conditions, which implies unconventional structural actions. Regulatory interventions are essential and need to be more proactive, define clear rules for granting subsidies and standardize specific situations, encouraging providers to expand WSS coverage in areas with high vulnerability.

The direct demand subsidy model in Chile is the most successful model currently in place in South America, benefiting about $12 \%$ of the population. It directly benefits low-income customers through state and municipal subsidies for the first cubic meters consumed and is classified in different percentages depending on the socioeconomic levels of each household. The Chilean model of formal subsidies has an explicit legal and regulatory framework with national coverage and is financed by general government funds that benefit customers from all regions, with clear policies for the periodic maintenance and renewal of benefits. In this way, direct demand-side subsidies offer an interesting contrast to indirect or supply-side subsidies or even cross-subsidies, providing more expressive and transparent results to universalize access to WSS. Two problems are simultaneously solved or mitigated, since on the one hand, the poor and vulnerable population increases its social and economic cohesion and, on the other hand, the water utilities receive a greater contribution towards their financial sustainability.

In Brazil, most of the tariff structures analyzed contain a social residential subdivision. The rates for this category are lower than the regular rate, thus characterizing mainly the cross-subsidy model. The social condition and geographical area of each customer are adopted as criteria for granting benefits, and despite the definition of subsidies contained in the federal law that regulates the WSS sector, it is not common to find direct demand subsidies for poor households. Due to the continental dimensions of Brazil and the country's distinctive reality, including the uneven distribution of income, the abundance and scarcity of water, relief systems, informal settlements, land ownership and even subnational regulation agencies, there is no clear rule about pro-poor subsidies and policies. Currently, there are few specific rules with economic and financial aspects for WSS subsidies in the country, and it is under the responsibility of regulatory agencies to develop more specific rules on tariffs, subsidies and regulatory accounting.

To expand the coverage and access to WSS, Brazil must opt for a policy of direct demand subsidies with very clear basic criteria for selecting customers. Supply-side subsidies should be kept although direct demand subsidy to consumption is still required. The tariff structure should take advantage of the cross-subsidization and include optimized blocks, and the percentage of subsidies established in each tariff block should be defined, along with the specific conditions and criteria for qualifying under the extreme poverty condition. The regulatory agencies might establish the criteria for connection and price subsidies, define subsidy levels that vary according to the income condition of each household and consider the most variable situations. The direct demand subsidy policy must set the sources of funds to cover the benefits with control and monitoring mechanisms, to correct economic and 
financial imbalances in the provision of WSS and to maintain the households' ability to pay. Therefore, Brazil needs to revise its national policy and strategy about pro-poor subsidies to guarantee the universal access to WSS and, particularly, the human right to water.

Author Contributions: D.A.N. reviewed the literature and developed the case studies. R.C.M. reviewed the paper and criticized the case studies and provided policy implications. All authors have read and agreed to the published version of the manuscript.

Funding: This research received no external funding.

Acknowledgments: The first author recognizes the help of the Intermunicipal Regulatory Agency-AGIR/SC in his studies.

Conflicts of Interest: The authors declare no conflict of interest.

\section{References}

1. Marques, R.C. Regulation of Water and Wastewater Services. An International Comparison; IWA Publishing: London, UK, 2010.

2. Ménard, C. Meso-institutions: The variety of regulatory arrangements in the water sector. Util. Policy 2017, 49, 6-19. [CrossRef]

3. Bel, G. Public versus private water delivery, remunicipalization and water tariffs. Util. Policy 2020, 62, 100982. [CrossRef]

4. Bardasi, E.; Wodon, Q. Who pays the most for water? Alternative providers and service costs in Niger. Econ. Bull. 2008, 9, 1-10.

5. Kayaga, S.; Franceys, R. Costs of urban utility water connections: Excessive burden to the poor. Util. Policy 2007, 15, 270-277. [CrossRef]

6. Whittington, D.; Nauges, C.; Fuente, D.; Wu, X. A diagnostic tool for estimating the incidence of subsidies delivered by water utilities in low- and medium-income countries, with illustrative simulations. Util. Policy 2015, 34, 70-81. [CrossRef]

7. Halpern, J.; Gómez-Lobo, A.; Foster, V. Designing Direct Subsidies for Water and Sanitation Services Panama-A Case Study; Policy Research; World Bank: Washington, DC, USA, 2000.

8. Halpern, J.; Walker, I.; Ordoñez, F.; Serrano, P. Pricing, Subsidies, and the Poor: Demand for Improved Water Services in Central America; World Bank: Washington, DC, USA, 1999.

9. De Hacienda, M. Evaluación de Impacto del Subsidio al Pago del Consumo de Agua Potable y Servicio de Alcantarillado y Tratamiento de Aguas Servidas; Ministerio de Hacienda: Santiago, Chile, 2017. Available online: https://www.dipres.gob.cl/597/articles-163133_informe_final.pdf (accessed on 25 May 2020).

10. Komives, K.; Foster, V.; Halpern, J.; Wodon, Q.; Abdullah, R. Water, Electricity, and the Poor: Who Benefits from Utility Subsidies? World Bank: Washington, DC, USA, 2005.

11. Komives, K.; Halpern, J.; Foster, V.; Wodon, Q.; Abdullah, R. The Distributional Incidence of Residential Water and Electricity Subsidies; World Bank: Washington, DC, USA, 2006.

12. Komives, K.; Halpern, J.; Foster, V.; Wodon, Q.; Abdullah, R. Utility Subsidies as Social Transfers: An Empirical Evaluation of Targeting Performance. Dev. Policy Rev. 2007, 25, 659-679. [CrossRef]

13. Ying, Y.; Skilling, H.; Banerjee, S.; Wodon, Q.; Foster, V. Cost Recovery, Equity, and Efficiency in Water Tariffs: Evidence from African Utilities; World Bank: Washington, DC, USA, 2010.

14. Foster, V. Toward a Social Policy for Argentina's Infrastructure Sectors: Evaluating the Past and Exploring the Future; World Bank: Washington, DC, USA, 2004.

15. Barde, J.A.; Lehmann, P. Distributional effects of water tariff reforms e an empirical study for Lima, Peru. Water Resour. Econ. 2014, 6, 30-57. [CrossRef]

16. Fuente, D.; Gatua, J.G.; Ikiara, M.; Kabubo-Mariara, J.; Mwaura, M.; Whittington, D. Water and sanitation service delivery, pricing, and the poor: An empirical estimate of subsidy incidence in Nairobi, Kenya. Water Resour. Res. 2016, 52, 4845-4862. [CrossRef]

17. Foster, V.; Araujo, C. Does Infrastructure Reform Work for the Poor? A Case Study from Guatemala; World Bank: Washington, DC, USA, 2004.

18. Angel-Urdinola, D.F.; Wodon, Q. Do utility subsidies reach the poor? Framework and evidence for Cape Verde, Sao Tome, and Rwanda. Econ. Bull. 2007, 9, 1-7. 
19. MIOPyV. Plan Nacional de Agua Potable y Saneamiento: Cobertura Universal Y Sostenibilidad de Los Servicios; Ministerio del Interior, Obras Públicas y Vivienda: Buenos Aires, Argentina, 2017.

20. Mercadier, A.C.; Brenner, F.S. Tariff (un)sustainability in contexts of price (in)stability: The case of the Buenos Aires water and sanitation concession. Util. Policy 2020, 63, 101005. [CrossRef]

21. MMAyA. Marco de Gestion Social y Evaluacion Social: Proyecto de Abastecimiento de Agua y Alcantarillado en Areas Periurbanas y Peqeñas Localidades; Ministerio de Medio Ambiente y Agua: La Paz, Bolivia, 2018.

22. MMAyA. Informe de Avances Hacia el Cumplimiento del Derecho Humano al Agua y al Saneamiento en Bolivia; Ministerio de Medio Ambiente y Agua: La Paz, Bolivia, 2017.

23. Del Saz-Salazar, S.; González-Gómez, F.; Guardiola, J. Willingness to pay to improve urban water supply: The case of Sucre, Bolivia. Water Policy 2015, 17, 112-125. [CrossRef]

24. MDR. 24 Diagnóstico dos Serviços de Água e Esgotos; Ministério do Desenvolvimento Regional: Brasília, Brazil, 2019.

25. SISS. Informe de Gestión del Sector Sanitario; Superintendencia de Servicios Sanitararios: Santiago, Chile, 2018.

26. Molinos-Senante, M. Urban water management. In Water Policy in Chile; Donoso, G., Ed.; Springer International Publishing: Cham, Switzerland, 2018; pp. 131-150.

27. Donoso, G. Water Policy in Chile; Springer International Publishing: Cham, Switzerland, 2018.

28. Molinos-Senante, M.; Donoso, G. Water scarcity and affordability in urban water pricing: A case study of Chile. Util. Policy 2016, 43, 107-116. [CrossRef]

29. Contreras, D.; Gómez-Lobo, A.; Palma, I. Revisiting the distributional impacts of water subsidy policy in Chile: A historical analysis from 1998-2015. Water Policy 2018, 20, 1208-1226. [CrossRef]

30. DNP. Plan Nacional de Desarrollo; Departamento Nacional de Planeación: Bogota, Colombia, 2015.

31. CGR. Gestión y Resultados del Sector de Agua Potable y Saneamiento Básico con Enfasis en los Recursos del Sistema General de Participaciones 1994-2017; Controladoría General de la República: Bogotá, Colombia, 2018.

32. Li, F.; Wang, W.; Ramírez, L.H.G. The determinants of two-dimensional service quality in the drinking water sector-Evidence from Colombia. Water Policy 2016, 18, 983-997. [CrossRef]

33. MAVDT. Costos y Tarifas Municipios Menores y Zonas Rurales; Ministério de Ambiente Vivendas e Desenvolvimento Territorial: Bogotá, Colombia, 2005.

34. MVCT. Plan Director Agua y Saneamiento Básico: Visión Estratégica 2018-2030; Ministerio de Vivienda, Ciudad y Territorio: Bogotá, Colombia, 2018.

35. DGEEC. Encuesta de Indicadores Múltiples por Conglomerados; Dirección General de Estadísticas Encuestas y Censos: Asuncion, Paraguay, 2016.

36. ERSSAN. Comité de Administración: Informe de Gestión 2017; Ente Regulador de Servicios Sanitarios: Asuncion, Paraguay, 2017.

37. MOPC. Plan Nacional de Agua Potable y Saneamiento; Ministerio de Obras Públicas y Comunicaciones: Asuncion, Paraguay, 2018.

38. INEI. Perú: Formas de Acceso Al Agua y Saneamiento Básico; Instituto Nacional de Estadística e Informática: Lima, Peru, 2019.

39. SUNASS. Planos Estratificados de Lima Metropolitana para Aplicar o Sistema de Subsídios Cruzados na Estrutura Tarifária da SEDAPAL S.A; Superintendência Nacional de Serviços de Saneamento-Resolução do Conselho de Administração N ${ }^{o}$ 021-2017-SUNASS-CD; Superintendência Nacional de Serviços de Saneamento: Lima, Peru, 2017.

40. Ioris, A.A.R. Water scarcity and the exclusionary city: The struggle for water justice in Lima, Peru. Water Int. 2016, 41, 125-139. [CrossRef]

41. Eagin, B.; Graham, J.P. A study of water and sanitation access trends in Peru: Where do inequities persist? J. Water Sanit. Hyg. Dev. 2014, 4, 499-508. [CrossRef]

42. Ferro, G. América Latina y el Caribe Hacia los Objetivos de Desarrollo Sostenible en Agua y Saneamiento; Reformas Recientes de las Políticas Sectoriales; CEPAL-AECID-UN: Santiago, Chile, 2017.

43. MVOTMA. Plan Nacional de Aguas; Ministerio de Vivienda, Ordenamiento Territorial y Medio Ambiente: Montevideo, Uruguay, 2017.

44. MIDES. Reporte Uruguay 2017; Ministerio de Desarrollo Social: Montevideo, Uruguay, 2017.

45. MVOTMA. Plan Nacional de Saneamiento; Ministerio de Vivienda, Ordenamiento Territorial y Medio Ambiente: Montevideo, Uruguay, 2019. 
46. URSEA. Régimen Tarifario; Unidad Reguladora de Servicios de Energía y Agua: Montevideo, Uruguay, 2019; Available online: https:/www.gub.uy/unidad-reguladora-servicios-energia-agua/politicas-y-gestion/ regimen-tarifario-0 (accessed on 4 February 2020).

47. ADERASA. Las Tarifas de Agua Potable y Alcantarillado en América Latina; Asociación de Entes Reguladores de Agua Potable y Saneamiento de las Américas: Asuncion, Paraguay, 2005.

48. MCidades. Proposta de Programas e Ações Estratégicas no Âmbito do Estudo Sobre Modelo de Subsídio às Famílias de Baixa Renda Aplicável aos Serviços de Abastecimento de Água e Esgotamento Sanitário; Ministério das Cidades: Brasília, Brazil, 2018.

49. Marques, R.D.C. Regulação de Serviços Públicos; Edições Sílabo: Lisbon, Portugal, 2005.

50. Andres, L.A.; Thibert, M.; Lombana Cordoba, C.; Danilenko, A.; Joseph, G.; Borja-Vega, C. Doing More with Less: Smarter Subsidies for Water Supply and Sanitation; World Bank: Washington, DC, USA, 2019.

51. Cook, J.; Fuente, D.; Matichich, M.; Whittington, D. A Global Assessment of Nontariff Customer Assistance Programs in Water Supply and Sanitation. In Development Studies in Regional Science; Chen, Z., Bowen, W., Whittington, D., Eds.; Springer: Singapore, 2020; pp. 315-371.

52. Cook, J.; Fuente, D.; Whittington, D. Choosing Among Pro-Poor Policy Options in the Delivery of Municipal Water Services. Water Econ. Policy 2020, 1950013, 1-21. [CrossRef]

53. IBGE. Censo Demográfico; Instituto Brasileiro de Geografia e Estatística: Rio de Janeiro, Brazil, 2010.

54. Guimaraes, E.; Malheiros, T.; Marques, R.C. Inclusive governance: New concept of water supply and sanitation services in social vulnerability areas. Util. Policy 2016, 43, 124-129. [CrossRef]

55. Guimarães, E.F. Modelo Inclusivo para a Universalização do Saneamento Básico em Áreas de Vulnerabilidade Social. Ph.D. Thesis, Universidade de São Paulo, São Paulo, Brazil, 2015.

56. Queiroz, V.C.; De Carvalho, R.C.; Heller, L. New Approaches to Monitor Inequalities in Access to Water and Sanitation: The SDGs in Latin America and the Caribbean. Water 2020, 12, 931. [CrossRef]

57. Marques, R.C.; Pinto, F.S.; Miranda, J. Redrafting Water Governance: Guiding the way to improve the status quo. Util. Policy 2016, 43, 1-3. [CrossRef]

58. Evans, B.; Alexander, I.; Brocklehurst, C.; Kariuki, M.; Komives, K.; Rosenthal, S.; Tremolet, S.; Triche, T. New Designs for Water and Sanitation Transactions: Making Private Sector Participation Work for the Poor; World Bank Water and Sanitation Program and PPIAF: Washington, DC, USA, 2004.

59. Dar, O.A.; Khan, M.S. Millennium development goals and the water target: Details, definitions and debate. Trop. Med. Int. Health 2011, 16, 540-544. [CrossRef] [PubMed]

60. United Nations (UN). The Human Right to Water and Sanitation Media Brief. 2011. Available online: http: //www.un.org/waterforlifedecade/pdf/human_right_to_water_and_sanitation_media_brief.pdf (accessed on 23 August 2019).

61. Lyra, D.H.S. Subsídios às Tarifas dos Serviços Públicos de Abastecimento de Água e Esgotamento Sanitário para Municípios sem Capacidade de Pagamento Compatível com a Autossustentação Econômico-Financeira: Concretização de Direitos Fundamentais; IDP: Brasília, Brazil, 2015.

62. UNESCO. The United Nations World Water Development Report 2015: Water for a Sustainable World; UNESCO: Paris, France, 2015. Available online: http://unesdoc.unesco.org/images/0023/002318/231823E.pdf (accessed on 20 August 2019).

63. Galvão Junior, A.C. Regulação e Universalização dos Serviços de Água e Esgoto: Estudo do Nordeste Brasileiro; USP: São Paulo, Brazil, 2008.

64. Fuente, D. The design and evaluation of water tariffs: A systematic review. Util. Policy 2019, $61,100975$. [CrossRef]

65. Galvão Júnior, A.C.; Monteiro, M.A.P.; Costa, S.A.B.; Cossenzo, C.S.; Oliveira Júnior, L.A.; Silva, A.C.; Sobrinho, G.B.; Freire, B.V. Tarifa Social nas Companhias Estadual de Saneamento Básico e o Papel da Regulação; ABAR: Brasília, Brazil, 2018.

(C) 2020 by the authors. Licensee MDPI, Basel, Switzerland. This article is an open access article distributed under the terms and conditions of the Creative Commons Attribution (CC BY) license (http://creativecommons.org/licenses/by/4.0/). 